(syn. Felis concolor) missoulensis across southern Alberta, Saskatchewan, and interior British Columbia; P. c. oregonensis along coastal British Columbia; and P. c. vancouverensis on Vancouver Island only. ${ }^{2,4,7}$ Latest reports indicate population sizes of around 4,500 cougars in Canada, with the highest concentration in British Columbia, over 600 in Alberta, and around 300 in Saskatchewan. ${ }^{1,3,5,6}$

1. BACON, M. and M. BOYCE. 2009. The prairie cougar: examining the effects of a re-established predator population. Nature Alberta 38(4).

2. CANADIAN GEOGRAPHIC. 2004. Cougar facts Canadian Geographic Magazine. Available online at: http://www.canadiangeographic.ca/Magazine/mj04/ indepth/justthefacts.asp

3. CULVER, M., W. E. JOHNSON, J. PECONSLATTERY and S. J. O'BRIEN. 2000. Genetic ancestry of the American puma (Puma concolor). Journal of Heredity 91:186-197.
4. DEWDNEY, A.K. 2001. Are there cougars among us? The Cardinal 184:20-23.

5. GOVERNMENT OF SASKATCHEWAN. 2007 NewsLine. Saskatchewan cougars. Available online: http://www.environment.gov.sk.cal Default.aspx?DN=0d6c5f37-8b 18-4a6a-8f6e$1001067161 \mathrm{eb}$

6. NORTHWEST WILDLIFE PRESERVATION SOCIETY. Mountain lion (Felis concolor). Available online at: http://www.northwestwildlife.com/pages/ kidscorner_Wildlife_wildcat.htm\#cougar

7. SCOTT, F.W. 1998. Updated COSEWIC status report on cougar (Puma concolor couguar) [Eastern population]. COSEWIC, Ottawa, ON. Available online at: http://www.cosewic.gc.ca/

- Saikat Kumar Basu, Department of Biological Sciences, University of Lethbridge, Lethbridge, AB, T1K 3M4; E-mail: <saikat.basu@uleth.ca>

\title{
UNUSUAL LARK SPARROW NESTING SITE
}

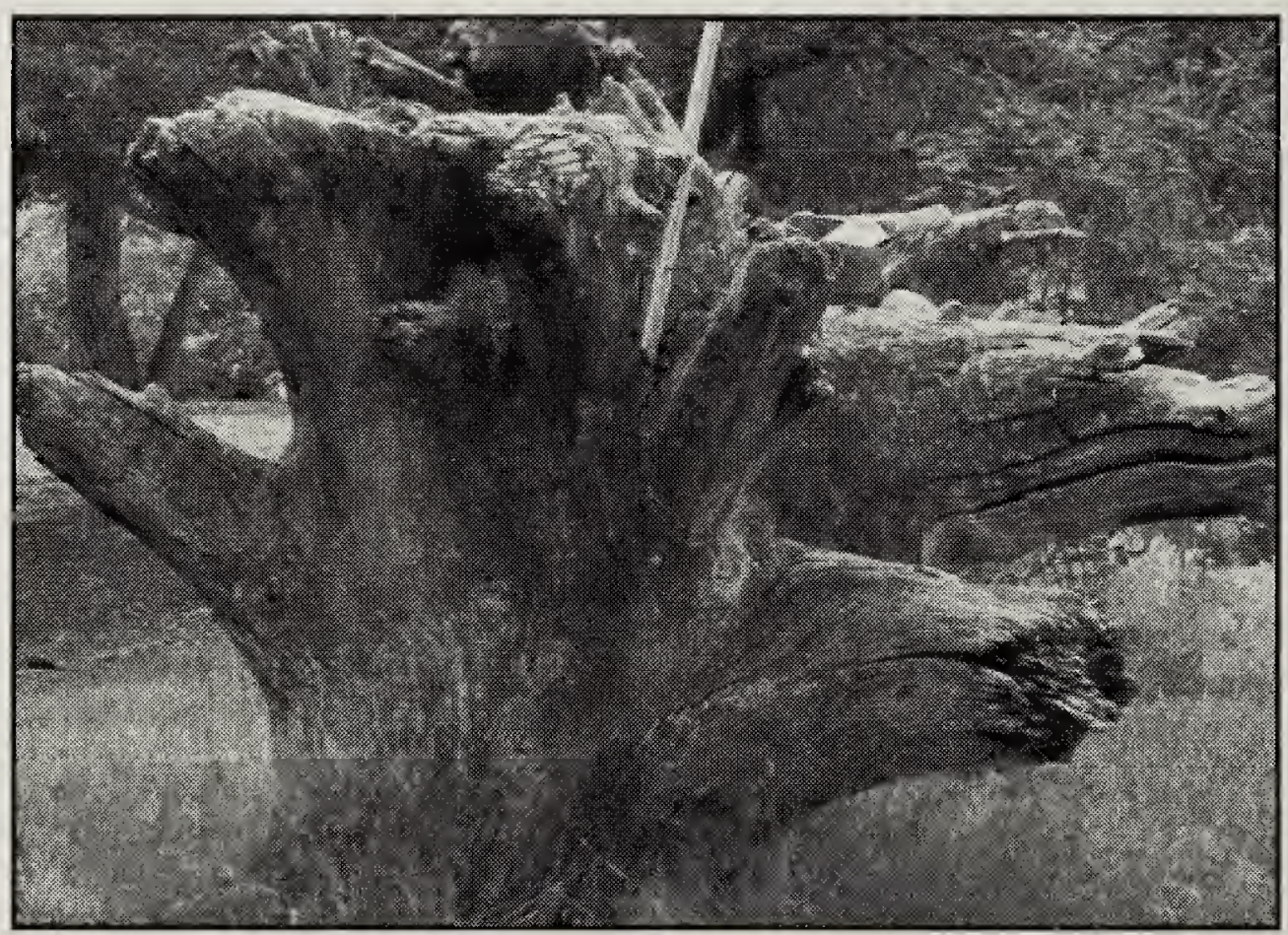

Lark Sparrow nest in an upturned tree stump. The nest can be seen in the top central portion of the stump.

Sig and Ruby Jordheim

and buried. In later years, many remnants of this interned riparian forest returned as driftwood, collecting on the eroded river banks. From among this driftwood, Sig and Ruby salvaged a large stump, planting it upside down as an abstract lawn ornament, or perhaps as a subtle commentary on man and nature. In any case, in the summer of 2009, a Lark Sparrow, undeterred by the peculiar location and position of the stump, made use of a hollow

Sig and Ruby Jordheim have farmed for many years in White Bear, Saskatchewan, near the South Saskatchewan River, where Sig has spent a lifetime closely observing wildlife. When the river was dammed in the 1960's, the groves of giant poplars lining the banks were bulldozed among the upturned roots for an unusual nesting site. Sig Jordheim writes: "Before starting school in 1928, I had a deep interest in birds and when my two older brothers went to school I searched for prairie bird nests. I was quite familiar with the Horned Lark, Vesper Sparrow, 


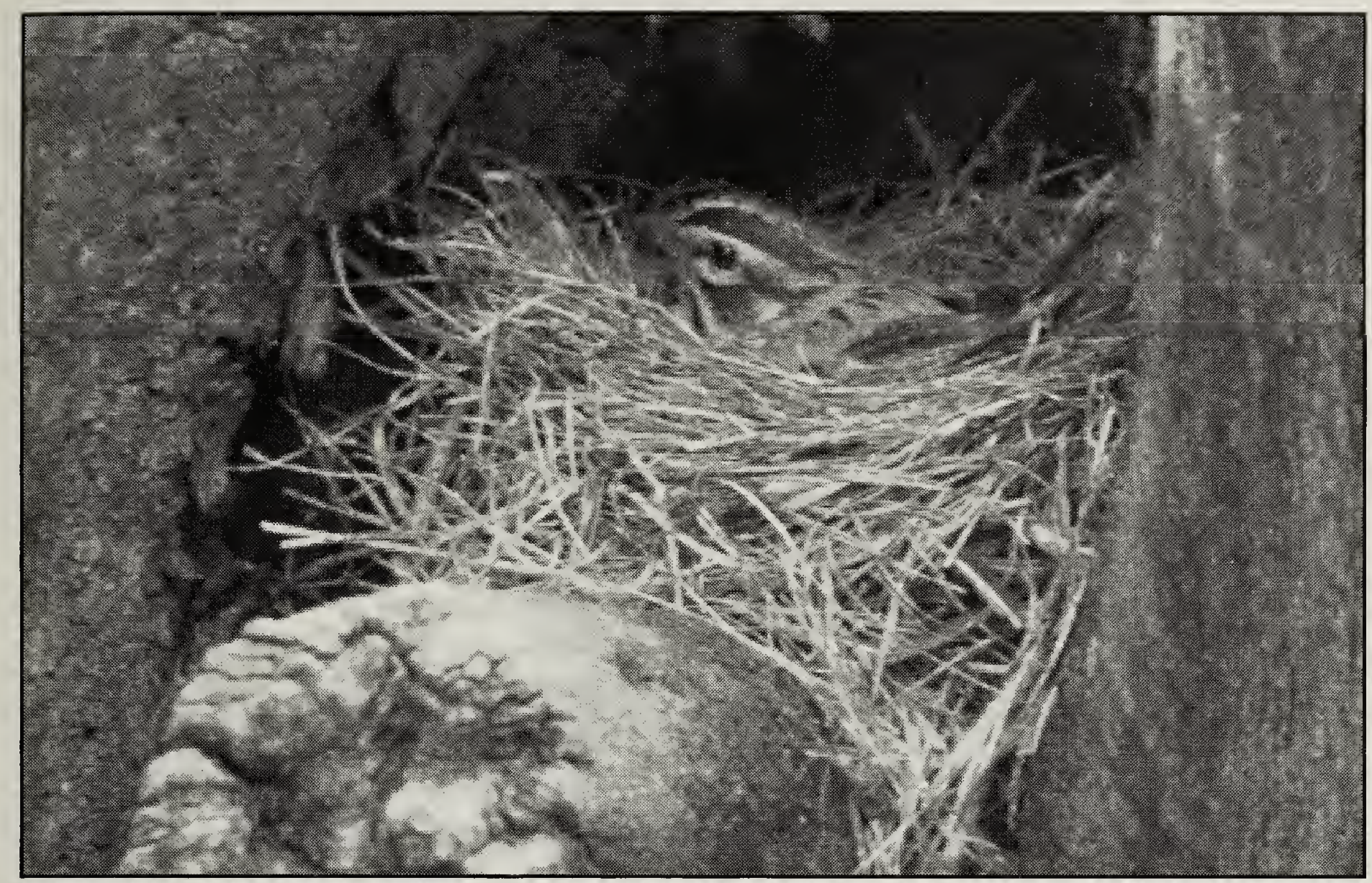

Close-up of the Lark Sparrow nest.

Sig and Ruby Jordheim

McCown's and Chestnut Coloured Longspurs. However, I took no notice of the Lark Sparrow until the 1960's when, on my own farm, I had established eight miles of field shelterbelt. I have usually found nests of these birds on the ground

and found the location of this particular nest unusual."

- Darryl Jordheim, Box 59, White Bear, SK, SOL 3L0. E-mail: <whitebearfarm@ sasktel.net>

Juvenile Rough-Legged Hawk.

Randy McCulloch 